\title{
Caloramator indicus sp. nov., a New Thermophilic Anaerobic Bacterium Isolated from the Deep-Seated Nonvolcanically Heated Waters of an Indian Artesian Aquifer
}

\author{
SONYA CHRISOSTOMOS, B. K. C. PATEL, ${ }^{*}$ PREM P. DWIVEDI, AND STUART E. DENMAN \\ Faculty of Science and Technology, Griffith University, Nathan, Brisbane, Queensland, Australia 4111
}

\begin{abstract}
A new thermophilic, glucose-fermenting, anaerobic isolate, strain IndiB4 ${ }^{\mathrm{T}}$, was obtained from the nonvolcanically heated waters of an Indian artesian basin bore and was named Caloramator indicus. The cells of this organism were rod shaped to filamentous and occurred singly, in pairs, or in short chains. Motility and spores were not observed. Electron micrographs of thin sections revealed a typical gram-positive cell wall structure, although the cells stained gram negative. The optimum temperature for growth was 60 to $65^{\circ} \mathrm{C}$, the maximum temperature was $75^{\circ} \mathrm{C}$, and the minimum temperature was more than $37^{\circ} \mathrm{C}$. Growth occurred at $\mathrm{pH}$ values between 6.2 and 9.2, and the optimum pH was between 7.5 and 8.1. The generation time of $C$. indicus at the optimal temperature and optimal $\mathrm{pH}$ was $20 \mathrm{~min}$. The DNA base composition was $25.6 \pm 0.3 \mathrm{~mol} \%$ guanine plus cytosine as determined by thermal denaturation. Strain IndiB4 $^{\mathrm{T}}$ utilized a wide range of carbohydrates, including starch, amylopectin, sucrose, mannose, lactose, fructose, and cellobiose. Ethanol, acetate, lactate, $\mathrm{CO}_{2}$, and $\mathrm{H}_{2}$ were the end products of glucose fermentation. Growth was inhibited by penicillin, tetracycline, and chloramphenicol, indicating that the organism is a member of the domain Bacteria. A phylogenetic analysis of the 16S rRNA gene revealed that strain $\mathrm{IndiB4}^{\mathrm{T}}$ is affiliated with the low-guanine-plus-cytosine-content subgroup of the gram-positive phylum. The type strain of $C$. indicus is strain IndiB4 (= ACM 3982).
\end{abstract}

Thermophilic microbes belonging to the domains Bacteria and Archaea have aroused a great deal of interest for the past decade because of their biotechnological potential and evolutionary significance. The primary habitats of thermophilic bacteria are naturally occurring volcanic marine and terrestrial hot springs, although some thermophilic bacteria (e.g., Thermus spp.) have been isolated from artificially heated environments and others (e.g., Bacillus stearothermophilus) have been isolated from nonthermal environments (23).

Thermophilic bacteria that occur in volcanic environments have been studied extensively, but relatively little attention has been paid to other naturally heated aquatic environments, such as the nonvolcanically heated waters of deep-seated aquifers. The waters of such aquifers are heated geothermally, and the temperature increases about $1^{\circ} \mathrm{C} / 30 \mathrm{~m}$ of depth (6). We recently isolated thermophilic bacteria from water samples obtained from the deep-seated aquifer known as the Great Artesian Basin of Australia, where the water temperature can reach $100^{\circ} \mathrm{C}(3,12,17)$, and in this paper we describe a new thermophilic anaerobe that was isolated from the nonvolcanically heated waters of an Indian artesian basin.

\section{MATERIALS AND METHODS}

Sample source. Water, sediment, and microbial mat samples were collected from the natural discharge areas of an artesian aquifer in Surat District, Gujarat State, India (24), by completely filling sterile glass containers. Temperature and $\mathrm{pH}$ were measured in situ during sampling. The samples were transported to our laboratory at Griffith University, Brisbane, Australia, and were stored at room temperature until they were used.

Enrichment and isolation. Samples $(0.5 \mathrm{ml})$ were inoculated into $10-\mathrm{ml}$ portions of prereduced anaerobic Trypticase-glucose-yeast extract (TYEG) medium to initiate enrichment cultures, and the resulting preparations were incubated at $70^{\circ} \mathrm{C}$ without agitation as described previously $(19.20)$. Pure cultures of positive enrichment cultures were obtained by end point dilution in TYEG medium containing $2.5 \%$ agar. Single colonies, which developed from the most dilute inoculum after 3 days of incubation, were picked and transferred into fresh liquid

\footnotetext{
* Corresponding author. Phone: 61-73-8757695. Fax: 61-73-8757800.
} Electronic mail address: B.Patel@sct.gu.edu.au.
TYEG medium. The process of end point dilution was repeated at least twice. The resulting culture was considered pure, and this was subsequently confirmed by the results of an analysis of its $16 \mathrm{~S}$ ribosomal DNA sequence.

Our new isolate was streaked onto TYEG agar plates, and the plates were incubated under an air atmosphere to test for aerobic growth.

Induction of spores was examined by using xylose-soil extract agar and a wide range of substrates and environmental parameters $(\mathrm{pH}$ and temperature). Heat resistance was also used to determine the presence of spores (9).

Growth tests and antibiotic susceptibility. The $\mathrm{pH}$ of TYEG medium was adjusted to values between 4.0 and 10.0 by adding $\mathrm{HCl}$ or $\mathrm{NaOH}$, and the resulting preparations were used to determine the $\mathrm{pH}$ range and optimum $\mathrm{pH}$. TYEG medium at the optimum $\mathrm{pH}$ was then used to determine the temperature range and optimum temperature. These experiments were repeated twice.

Substrate utilization tests were performed by using TYE medium (TYEG medium without glucose) containing various carbon sources (from 10\% sterile stock solutions) at final concentrations of $0.5 \%$ and were repeated twice.

Antibiotic susceptibility tests were performed with TYEG medium. Chloramphenicol, neomycin sulfate, novobiocin, penicillin G, polymyxin B, rifampin, streptomycin sulfate, tetracycline- $\mathrm{HCl}$, and vancomycin were prepared as filtersterilized stock solutions and added to final concentrations of 10 and $100 \mu \mathrm{g} / \mathrm{ml}$ TYEG medium that lacked antibiotics was used as the control. Following inoculation and incubation at $68^{\circ} \mathrm{C}$ for $4.5 \mathrm{~h}$, the optical density at $660 \mathrm{~nm}$ was determined. The levels of inhibition of growth due to the presence of antibiotics were estimated by comparing the growth obtained in the presence of antibiotics with the growth obtained in control tubes containing TYEG medium that lacked antibiotics.

Growth and fermentation product analysis. Growth was measured by determining turbidity at $660 \mathrm{~nm}$ (length of light path, $1 \mathrm{~cm}$ ) by inserting culture tubes directly into a NovaSpec spectrophotometer (Pharmacia).

Fermentation end products were determined by using gas-liquid chromatography. A Shimadzu model GC8 apparatus equipped with a thermal conductivity detector was used to analyze $\mathrm{CO}_{2}$ and $\mathrm{H}_{2}$. The gases were separated on a Carbosphere (80/100) column by using $\mathrm{N}_{2}$ at a flow rate of $8 \mathrm{ml} / \mathrm{min}$ as the carrier gas. A Shimadzu model GC14 apparatus equipped with a flame ionization detector was used to analyze volatile fatty acids and lactate. The acids were separated on a Chromosorb $101(80 / 100)$ column by using $\mathrm{N}_{2}$ at a flow rate of 12.5 $\mathrm{ml} / \mathrm{min}$ as the carrier gas and $\mathrm{H}_{2}$ and air at flow rates of 18 and $250 \mathrm{ml} / \mathrm{min}$, respectively, as the flame gases. The oven temperature and the injector temperature were kept at 180 and $200^{\circ} \mathrm{C}$, respectively. The amounts of the gases and the acids were determined as described previously (20), except that Delta, a computer software analysis package (Digital Solutions, Ltd., Brisbane, Queensland, Australia), was used to integrate the peaks.

Cellular characterization. Light microscopy and electron microscopy were performed as described previously (12).

$\mathbf{G}+\mathbf{C}$ content and screening for plasmids. DNA was isolated and purified by the method of Marmur (13). The DNA was resuspended in $0.1 \times$ SSC buffer $(1 \times$ SSC is $0.15 \mathrm{M} \mathrm{NaCl}$ plus $0.015 \mathrm{M}$ sodium citrate), and denaturation was deter- 

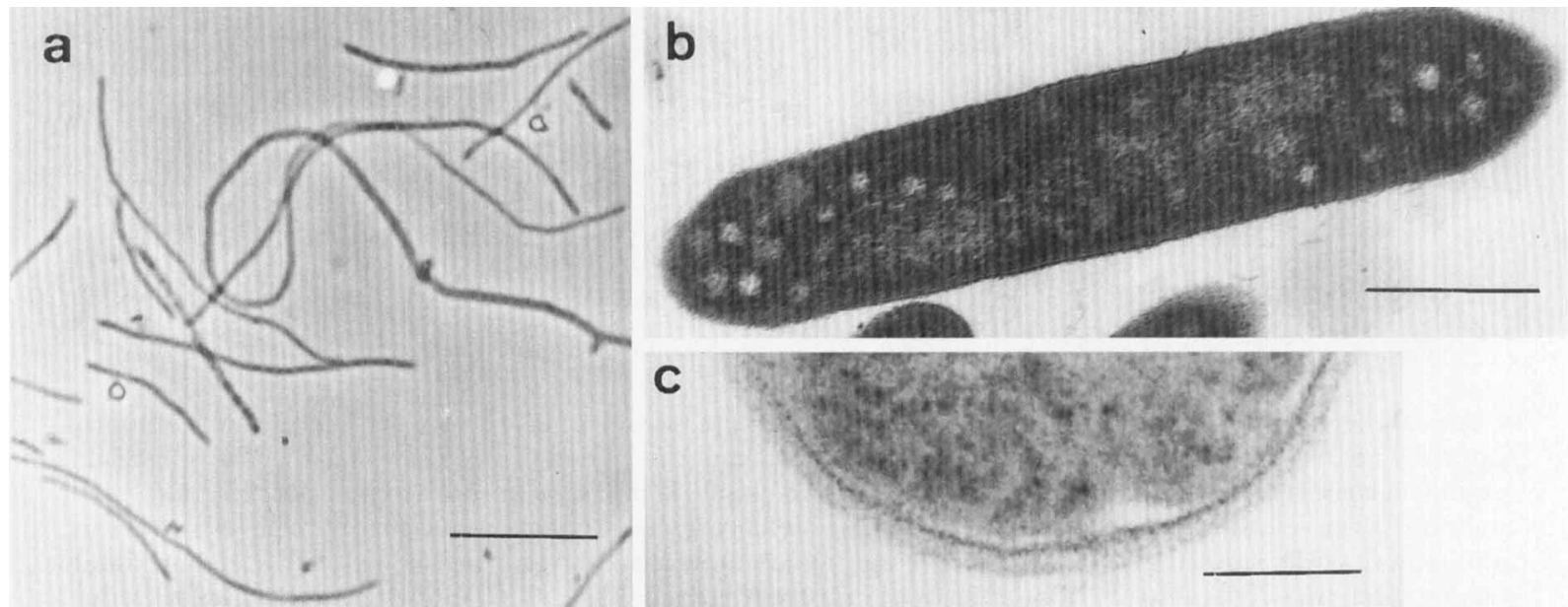

C

FIG. 1. (a) Phase-contrast micrograph of isolate IndiB4 $4^{\mathrm{T}}$ showing the presence of dense granular bodies inside filamentous cells. Bar $=5 \mu \mathrm{m}$. (b) Electron micrograph of a whole cell showing electron-light inclusions. Bar $=0.5 \mu \mathrm{m}$. (c) Electron micrograph showing the gram-positive nature of the cell wall. Bar $=0.1 \mu \mathrm{m}$.

mined with a Gilford model 250 spectrophotometer equipped with a thermoprogrammer. DNA from a reference strain, Escherichia coli ACM 1803 (Australian Collection of Microorganisms, The University of Queensland, St. Lucia, Queensland, Australia), was purified by using the procedure described above and was used as a standard to calculate the DNA base composition. The DNA was also used for 16S rRNA gene amplification (see below).

Mid-log-phase and stationary-phase cultures were examined for the presence of plasmids by using a previously described method (3).

16S rRNA sequence studies. Amplification and purification of the $16 \mathrm{~S}$ rRNA gene were performed as described previously $(12,22)$. The purified PCR product was sequenced directly or cloned and sequenced. The method used to clone the $16 \mathrm{~S}$ rRNA genes has been described previously (12). The sequence was determined with an ABI automated DNA sequencer by using a Prism dideoxy terminator cycle sequencing kit as recommended by the manufacturer (Applied Biosystems, Ltd., Foster City, Calif.). The primers used for sequencing have been described previously (22)

The $16 \mathrm{~S}$ ribosomal rDNA sequence obtained from the sequencing data was aligned with the sequences of various members of the bacterial phylum by using sequence editor ae $2(16)$, whose $16 \mathrm{~S}$ rRNA sequences were obtained from the rRNA database and from GenBank. Positions of sequence and alignment uncertainty (positions 1 to 12,53 to 102,183 to 219,452 to 480,838 to 849,905 to 968,1019 to 1044,1131 to 1143,1366 to 1386,1449 to 1455 , and 1483 to 1542 according to Winker and Woese [26]) were omitted from the analysis. Pairwise evolutionary distances were computed by using Olsen's correction parameter of Jukes and Cantor $(8,14)$, and dendrograms were constructed by using the program of De Soete (4). A transversion analysis was performed by using the program DNAPARS implemented in the PHYLIP package (5). Tree topology was reexamined by using 100 bootstrapped data sets; the SEEQBOOT, DNADIST, FITCH, and CONSENSE programs available in the PHYLIP package (5) and programs available on TREECON (25) were used to do this.

Nucleotide sequence accession number. The EMBL accession number of the $16 \mathrm{~S}$ rRNA gene sequence of strain IndiB4 $^{\mathrm{T}}$ is $\mathrm{X} 75788$.

\section{RESULTS}

Enrichment and isolation. Positive enrichment cultures developed from two of four samples that were inoculated into TYEG medium and incubated at $70^{\circ} \mathrm{C}$ within $48 \mathrm{~h}$. The $\mathrm{pH}$ values of all four samples were 7.7 to 7.8 . The temperatures of the two samples that gave rise to positive enrichment cultures were 60 and $65^{\circ} \mathrm{C}$, and these samples contained no microbial mats, whereas the two samples that did not give rise to positive enrichment cultures contained microbial mats and their temperatures were 55 and $58^{\circ} \mathrm{C}$. A pure culture obtained from the enrichment culture obtained from the $65^{\circ} \mathrm{C}$ sample, designated strain IndiB4 $4^{\mathrm{T}}(\mathrm{T}=$ type strain $)$, was studied further. Phenotypically similar strains were isolated from the sample even after 2 years, indicating that transport and storage of the sample at ambient temperature did not affect the viability of the organisms.
Isolate IndiB $4^{\mathrm{T}}$ was a strict anaerobe and did not grow on TYEG agar plates that were incubated aerobically.

Morphology and cell structure. Isolate IndiB $4^{\mathrm{T}}$ was a nonmotile rod-shaped organism, but filamentous cells (10 to 100 by 0.6 to $0.8 \mu \mathrm{m}$ ) were also observed routinely when the organism was incubated in TYEG medium (Fig. 1a). Electron microscopy of negatively stained cells did not reveal the presence of flagella. Spores were not observed in cultures that had been grown in the presence of a wide range of substrates (glucose, starch, mannose, and sucrose), at different $\mathrm{pH}$ values ( $\mathrm{pH} 6$ to 9.0 ), at different temperatures $\left(45\right.$ to $70^{\circ} \mathrm{C}$ ), or in xylose-soil extract medium. In addition, after log- or stationaryphase cultures had been incubated at $80^{\circ} \mathrm{C}$ for $20 \mathrm{~min}$, no growth occurred when the cultures were inoculated into fresh TYEG medium. Thus, heat-resistant bodies, such as spores, were absent.

Cells in stationary-phase cultures that had been grown at $65^{\circ} \mathrm{C}$ at a low $\mathrm{pH}$ (e.g., $\left.\mathrm{pH} 7.2\right)$ lysed more readily than cells in stationary-phase cultures that had been grown at a higher $\mathrm{pH}$ (e.g., pH 8.1).

When isolate IndiB $4^{\mathrm{T}}$ was grown in TYEG medium, dense granular bodies were observed in the cytoplasm with a phasecontrast microscope; these bodies may have been storage granules. Granules also appeared in electron micrographs of thin sections (Fig. 1b). Isolate IndiB $4^{\mathrm{T}}$ had the cell wall ultrastructure of a gram-positive bacterium (Fig. 1c).

Optimal growth conditions. Isolate IndiB $4^{\mathrm{T}}$ grew in TYEG medium at $\mathrm{pH} 6.2$ to 9.2 , and optimal growth occurred at $\mathrm{pH}$ 8.1 (Fig. 2). No growth occurred at a temperature of $37^{\circ} \mathrm{C}$ or

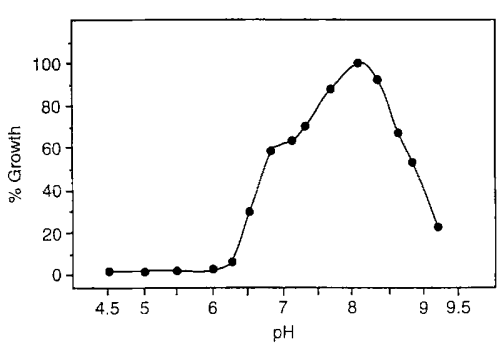

FIG. 2. Growth of isolate IndiB $4^{\mathrm{T}}$ in TYEG medium as a function of $\mathrm{pH}$. Absorbance was determined after $4.5 \mathrm{~h}$ of growth at $65^{\circ} \mathrm{C} ; 100 \%$ growth was equivalent to an optical density of 0.86 . 


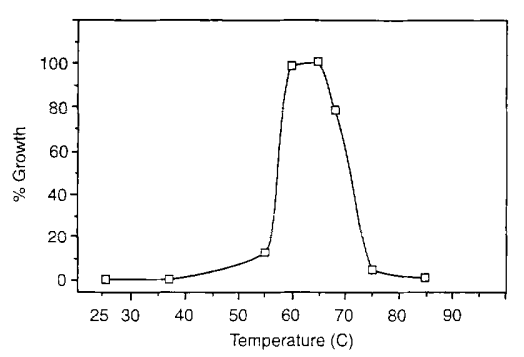

FIG. 3. Growth of isolate IndiB $4^{\mathrm{T}}$ in TYEG medium ( $\mathrm{pH} 8.1$ ) as a function of temperature. Absorbance was determined after $5.5 \mathrm{~h}$ of incubation; $100 \%$ growth was equivalent to an optical density of 0.95 .

below or at temperatures above $75^{\circ} \mathrm{C}$. The optimal growth temperature was between 60 and $65^{\circ} \mathrm{C}$ (Fig. 3). The generation time at the optimal temperature and optimal pH was $20 \mathrm{~min}$.

Substrate utilization and fermentation end products. The substrates that supported growth included glucose, amylopectin, starch, amylose, dextrin, cellobiose, fructose, lactose, mannose, and sucrose (Table 1). Although Trypticase peptone and/or yeast extract was required for growth on these carbohydrates, the carbohydrates could also be fermented when no substrates were added. The substrates that did not support growth include carboxymethyl cellulose, cellulose, chitin, and dextran.

The primary end products formed during glucose fermentation included ethanol, acetate, lactate, $\mathrm{CO}_{2}$, and $\mathrm{H}_{2}$. In addition, isobutyrate, $n$-butyrate, isovalerate, and $n$-valerate were produced. These end products were also detected during growth on Trypticase peptone when no carbohydrates were added. A fermentation balance of glucose utilized and end products formed was not possible because of interference by the products of yeast extract and Trypticase peptone metabolism.

Antibiotic susceptibility. Growth of isolate $\operatorname{IndiB}^{\mathrm{T}}$ in TYEG medium was completely inhibited by $10 \mu \mathrm{g}$ of penicillin $\mathrm{G}$ per $\mathrm{ml}, 10 \mu \mathrm{g}$ of chloramphenicol per $\mathrm{ml}, 10 \mu \mathrm{g}$ of novobiocin per $\mathrm{ml}, 10 \mu \mathrm{g}$ of polymyxin B per $\mathrm{ml}, 10 \mu \mathrm{g}$ of rifampin per $\mathrm{ml}, 10 \mu \mathrm{g}$ of tetracycline per $\mathrm{ml}$, and $10 \mu \mathrm{g}$ of vancomycin per $\mathrm{ml}$ and was partially inhibited by $10 \mu \mathrm{g}$ of neomycin per $\mathrm{ml}$ and $10 \mu \mathrm{g}$ of streptomycin per $\mathrm{ml} ; 100 \mu \mathrm{g}$ of neomycin per $\mathrm{ml}$ and $100 \mu \mathrm{g}$ of streptomycin per ml completely inhibited growth.

DNA base composition. We calculated that the DNA base composition of isolate IndiB $4^{\mathrm{T}}$ was $25.6 \pm 0.3 \mathrm{~mol} \% \mathrm{G}+\mathrm{C}$

TABLE 1. Substrate utilization by isolate IndiB4 ${ }^{\mathrm{T} a}$

\begin{tabular}{lcc}
\hline \multicolumn{1}{c}{ Substrate } & Optical density & Final pH after growth \\
\hline TYE medium control & 0.397 & 7.35 \\
Amylopectin & 0.696 & 6.88 \\
Starch & $\mathrm{ND}^{b}$ & 5.82 \\
Amylose & 0.456 & 6.96 \\
Dextrin & $\mathrm{ND}$ & 6.31 \\
Cellobiose & 0.437 & 6.99 \\
Fructose & 0.515 & 6.13 \\
Glucose & 0.559 & 6.12 \\
Lactose & 0.422 & 6.95 \\
Mannose & 0.519 & 6.19 \\
Sucrose & 0.633 & 5.87 \\
\hline
\end{tabular}

${ }^{a}$ A substrate with which an increase in optical density at $660 \mathrm{~nm}$ or a decrease in $\mathrm{pH}$ compared with the TYE medium control was observed was considered negative for growth. Such substrates included cellulose, sorbitol, sorbose, carboxymethyl cellulose, and dextran.

${ }^{b} \mathrm{ND}$, not determined.

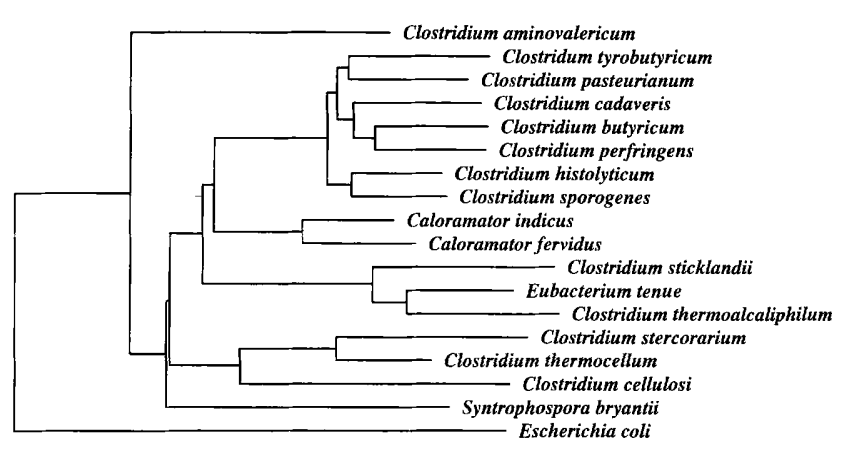

.10

FIG. 4. Dendrogram showing the position of isolate IndiB $4^{\mathrm{T}}$ among representatives of the genus Clostridium and other related bacteria. Bar $=0.1$ (evolutionary distance).

from a melting point of $65.8^{\circ} \mathrm{C}$ (an average of three separate measurements). The $E$. coli reference DNA had a melting temperature of $76.6^{\circ} \mathrm{C}$, corresponding to a $\mathrm{G}+\mathrm{C}$ content of $51.2 \mathrm{~mol} \%$. The $\mathrm{G}+\mathrm{C}$ content of Caloramator fervidus DNA is $39 \mathrm{~mol} \%$.

Phylogeny. The sequence of the $16 \mathrm{~S}$ rRNA gene of IndiB4 $4^{\mathrm{T}}$ was determined, and the $\mathrm{G}+\mathrm{C}$ content of the gene was 57.4 mol\%. Sequence alignment followed by a phylogenetic analysis revealed that this organism belongs to the subphylum containing gram-positive bacteria with DNA $\mathrm{G}+\mathrm{C}$ contents less than $55 \mathrm{~mol} \%$ and clusters with members of the clostridial group. A recent phylogenetic analysis of the $16 \mathrm{~S}$ rRNAs of members of the clostridial group revealed that there are at least 19 defined phylogenetic clusters and several distinct lines of descent. This led to the creation of five new genera and 11 new species combinations to accommodate phylogenetically distinct organisms (1). A sequence analysis performed with various clostridia revealed that isolate IndiB $4^{\mathrm{T}}$ is closely related to Caloramator fervidus (level of similarity, 93.1\%). Both of these organisms in turn appeared to be peripherally related to members of clostridium group I as defined by Johnson and Francis (7) or cluster I as defined by Collins et al. (1) (average level of similarity, $87.7 \%$ ). Caloramator fervidus was formerly described as Clostridium fervidus (18). However, because this organism was shown to belong to a distinct line of descent $(1,21)$, it was transferred to a new genus by Collins et al. (1). A dendrogram that was generated by the method of De Soete (4) from the evolutionary distance matrix and shows this relationship is shown in Fig. 4. Our bootstrap analysis of the data as implemented in the PHYLIP package (5) and the TREECON package (25) gave similar results, and both methods indicated that the relationship of Caloramator fervidus and isolate IndiB $4^{T}$ was robust $(100 \%)$ and that the relationship of these taxa to members of clostridium group I was also robust. We have also isolated and identified a number of novel thermophilic bacteria from the nonvolcanically heated waters of the Great Artesian Basin of Australia which fall into this subgroup, and these organisms are currently being characterized.

\section{DISCUSSION}

The microbiology of nonvolcanically heated aquifers has not been studied as well as the microbiology of volcanically heated waters, and only thermophilic sulfate-reducing bacteria have 
been found in such ecosystems previously $(2,12,15)$. The discovery of isolate IndiBB $4^{\mathrm{T}}$ broadens the known diversity of thermophilic microbes in such ecosystems to include glucosefermenting anaerobes.

Isolate IndiB $4^{\mathrm{T}}$ is a thermophilic (optimum growth temperature, 60 to $65^{\circ} \mathrm{C}$ ), glucose-fermenting anaerobe with rodshaped to filamentous morphology, and hence it resembles numerous volcanic isolates and a few cultures isolated from nonvolcanically heated environments, such as compost. However, the $\mathrm{G}+\mathrm{C}$ content of isolate IndiB $4^{\mathrm{T}}$ is $25.6 \pm 0.3 \mathrm{~mol} \%$, which is significantly lower than the $\mathrm{G}+\mathrm{C}$ contents of all previously described thermophilic bacteria, whose $\mathrm{G}+\mathrm{C}$ contents range from 30 to $55 \mathrm{~mol} \%$. In addition, the optimum $\mathrm{pH}$ of isolate IndiB $4^{\mathrm{T}}$ is somewhat higher $(\mathrm{pH} 8.1)$ than the optimum $\mathrm{pH}$ values of most other thermophilic anaerobes that have been described ( $\mathrm{pH} 7$ to 7.5 ); the only exceptions to this are two moderately thermophilic alkaliphiles that were described recently $(10,11)$.

Isolate IndiB4 ${ }^{\mathrm{T}}$ is gram negative but has a typical grampositive cell wall ultrastructure. Although spore formation has not been demonstrated in isolate IndiB $4^{\mathrm{T}}$, our $16 \mathrm{~S}$ rRNA sequence analysis revealed that the nearest relatives are the sporulating gram-positive clostridia. Further analysis revealed that the closest relative of isolate IndiB $4^{T}$ is a sporulating thermophile, Caloramator fervidus, with which it shares some signature nucleotides, although nucleotides which differentiate these organisms have also been identified (unpublished data). Close phylogenetic relationships between nonsporulating bacteria and gram-positive sporulating bacteria are not uncommon, and some of these relationships have been described recently (21). Indeed, the value of spore formation as an important criterion in classification has also been questioned recently. This has led to revision of the genera Thermoanaerobacter and Thermoanaerobacterium and inclusion of sporeforming and non-spore-forming thermophilic species in these genera $(1,9)$.

Both isolate IndiB $4^{\mathrm{T}}$ and Caloramator fervidus are also able to grow well on Trypticase peptone and/or yeast extract without any added carbon source, and these organisms produce similar fermentation end products (18). However, morphology, $\mathrm{G}+\mathrm{C}$ content, and sporulation can be used to differentiate isolate IndiB $4^{\mathrm{T}}$ and Caloramator fervidus. Clearly, isolate IndiB4 $4^{\mathrm{T}}$ is a novel thermophilic bacterium which is phenotypically distinct from all thermophilic glucose-fermenting anaerobes described previously. However, it is phylogenetically related to Caloramator fervidus; therefore, we propose that isolate IndiB $4^{\mathrm{T}}$ should be placed in a new species of the genus Caloramator, Caloramator indicus.

Description of Caloramator indicus. Caloramator indicus (in'di.cus. M.L. gen. n. indicus, of India, the country from which the organism was isolated). Rods to filamentous cells that are 10 to $100 \mu \mathrm{m}$ long by 0.6 to $0.8 \mu \mathrm{m}$ wide. Gram negative. Does not sporulate. Nonmotile.

Chemoorganotrophic and obligately anaerobic. The optimum temperature for growth is 60 to $65^{\circ} \mathrm{C}$, and no growth occurs at temperatures below $37^{\circ} \mathrm{C}$ or above $75^{\circ} \mathrm{C}$. The optimum $\mathrm{pH}$ is between 7.5 and 8.1 , and no growth occurs at $\mathrm{pH}$ values below 6.2 or above 9.2. Utilizes glucose, amylopectin, starch, amylose, dextrin, cellobiose, fructose, lactose, mannose, and sucrose. Produces ethanol, acetate, lactate, $\mathrm{CO}_{2}$, and $\mathrm{H}_{2}$ during fermentation on glucose. Cellulose, dextran, and chitin are not fermented. Requires Trypticase peptone and/or yeast extract for growth on carbohydrates; both of these compounds can also be utilized in the absence of carbohydrates. Growth is inhibited by tetracycline, penicillin $\mathrm{G}$, chloramphenicol, novobiocin, polymyxin $\mathrm{B}$, and rifampin.
The $\mathrm{G}+\mathrm{C}$ content of the DNA is $25.6 \pm 0.3 \mathrm{~mol} \%$, as determined by thermal denaturation.

Phylogenetically related to Caloramator fervidus on the basis of the results of a $16 \mathrm{~S}$ rRNA sequence analysis.

The habitat is nonvolcanically heated waters that are hot because of the great depth of the aquifer. The location where the type strain was obtained is in Surat District, Gujarat State, India.

The type strain is strain IndiB4 (= ACM 3982).

\section{ACKNOWLEDGMENTS}

The financial assistance of the Griffith University Research Grants Committee and the Australian Research Council to B.K.C.P. is gratefully acknowledged.

We thank Lindsay Sly for the use of the Gilford spectrophotometer and for providing the E. coli type strain. We thank Deb Stenzel for assistance with electron microscopy.

\section{REFERENCES}

1. Collins, M. D., P. A. Lawson, A. Willems, J. J. Cordoba, J. FernandezGarayzabal, P. Garcia, J. Cai, H. Hippe, and J. A. E. Farrow. 1994. The phylogeny of the genus Clostridium: proposal of five new genera and eleven new species combinations. Int. J. Syst. Bacteriol. 44:812-826.

2. Daumas, S., R. Cord-Ruwisch, and J. L. Garcia. 1985. Desulfotomaculum geothermicum sp. nov., a thermophilic, fatty acid-degrading, sulfate-reducing bacterium isolated with $\mathrm{H}_{2}$ from geothermal groundwater. Antonie Leeuwenhoek 54:165-178.

3. Denman, S., K. Hampson, and B. K. C. Patel. 1991. Isolation of strains of Thermus aquaticus from the Australian Artesian Basin and a simple and rapid procedure for the preparation of their plasmids. FEMS Microbiol. Lett. 82:73-78.

4. De Soete, G. 1983. A least squares algorithm for fitting additive trees to proximity data. Psychometrika 48:621-626.

5. Felsenstein, J. 1993. PHYLIP (Phylogenetic inference package), version 3.51c. Department of Genetics, University of Washington, Seattle.

6. Habermehl, M. A. 1980. The Great Artesian Basin, Australia. BMR (Bur. Miner. Resour.) J. Aust. Geol. Geophys. 5:9-38.

7. Johnson, J. L., and B. L. Francis. 1975. Taxonomy of the clostridia: ribosomal ribonucleic acid homology among the species. J. Gen. Microbiol. 88:229-244.

8. Jukes, T. H., and C. R. Cantor. 1969. Evolution of protein molecules, p. 21-132. In H. N. Munro (ed.), Mammalian protein metabolism. Academic Press, New York.

9. Lee, Y.-E., M. K. Jain, C. Lee, S. E. Lowe, and J. G. Zeikus. 1993. Taxonomic distinction of saccharolytic thermophilic anaerobes: description of Thermoanaerobacterium xylanolyticum gen. nov., sp. nov., and Thermoanaerobacterium saccharolyticum gen. nov., sp. nov.; reclassification of Thermoanaerobium brockii, Clostridium thermosulfurogenes, and Clostridium thermohydrosulfuricum E100-69 as Thermoanaerobacter brockii comb. nov., Thermoanaerobacterium thermosulfurigenes comb. nov., and Thermoanaerobacter thermohydrosulfuricus comb. nov., respectively; and transfer of Clostridium thermohydrosulfuricum 39E to Thermoanaerobacter ethanolicus. Int. J. Syst. Bacteriol. 43: 41-51.

10. Li, Y., M. Engle, N. Weiss, M. Mandelco, and J. Wiegel. 1994. Clostridium thermoalcaliphilum sp. nov., an anaerobic and thermotolerant facultative alkaliphile. Int. J. Syst. Bacteriol. 44:111-118.

11. Li, Y., M. Mandelco, and J. Wiegel. 1993. Isolation and characterization of a moderately thermophilic alkaliphile, Clostridium paradoxum sp. nov. Int. J. Syst. Bacteriol. 43:450-460.

12. Love, C. A., B. K. C. Patel, P. D. Nichols, and E. Stackebrandt. 1993. Desulfotomaculum australicum, sp. nov., a thermophilic sulfate-reducing bacterium isolated from the Great Artesian Basin of Australia. Syst. Appl. Microbiol. 16:244-251.

13. Marmur, J. 1961. A procedure for the isolation of deoxyribonucleic acid from bacteria. J. Mol. Biol. 3:208-218.

14. Olsen, G. J. 1988. Phylogenetic analysis using ribosomal RNA. Methods Enzymol. 164:793-812.

15. Olsen, G. J., W. S. Dockins, G. A. McFeters, and W. P. Iverson. 1981. Sulfate-reducing and methanogenic bacteria from deep aquifers in Montana. Geomicrobiol. J. 2:327-340.

16. Olsen, G. J., N. Larsen, and C. R. Woese. 1991. The Ribosomal RNA Database Project. Nucleic Acids Res. 19:2017-2021.

17. Patel, B. K. C., C. A. Love, and E. Stackebrandt. 1992. Helix 6 of the $16 \mathrm{~S}$ rRNA of the bacterium Desulfotomaculum australicum exhibits an unusual structural idiosyncrasy. Nucleic Acids Res. 20:5483.

18. Patel, B. K. C., C. Monk, H. Littleworth, H. W. Morgan, and R. M. Daniel. 
1987. Clostridium fervidus sp. nov., a chemoorganotrophic acetogenic thermophile. Int. J. Syst. Bacteriol. 37:123-126.

19. Patel, B. K. C., H. W. Morgan, and R. M. Daniel. 1985. A simple and efficient method for preparing and dispensing anaerobic media. Biotechnol. Lett. 7:277-288.

20. Patel, B. K. C., H. W. Morgan, and R. M. Daniel. 1985. Fervidobacterium nodosum gen. nov. and spec. nov., a new chemoorganotrophic, caldoactive, anaerobic bacterium. Arch. Microbiol. 141:63-69.

21. Rainey, F. A., N. L. Ward, H. W. Morgan, R. Toalster, and E. Stackebrandt 1993. Phylogenetic analysis of anaerobic thermophilic bacteria: aid for their reclassification. J. Bacteriol. 175:4772-4779.

22. Redburn, A. C., and B. K. C. Patel. 1993. Phylogenetic analysis of Desulfotomaculum thermobenzoicum using polymerase chain reaction-amplified $16 \mathrm{~S}$
rRNA-specific DNA. FEMS Microbiol. Lett. 113:81-86.

23. Sharp, R. J., P. W. Riley, and D. White. 1992. Heterotrophic thermophilic bacilli, p. 19-50. In J. K. Kristjansson (ed.), Thermophilic bacteria. CRC Press, Boca Raton, Fla.

24. Thomas, J., and E. A. Gonzalves. 1965. Thermal algae of western India. Hydrobiologia 26:21-65.

25. Van de Peer, Y., and R. De Wachter. 1992. TREECON: a software package for the construction and drawing of evolutionary trees. Comput. Appl. Biosci. 9:177-182.

26. Winker, S., and C. R. Woese. 1991. A definition of the domains Archaea, Bacteria and Eucarya in terms of small subunit ribosomal RNA characteristics. Syst. Appl. Microbiol. 14:305-310. 